\title{
ANALISA FAKTOR ORGANISASI TERHADAP KINERJA KESELAMATAN ORGANISASI
}

\author{
Nimas Mayangsari ${ }^{1}$, Zulkifli Djunaidi ${ }^{2}$ \\ Departemen Kesehatan dan Keselamatan Kerja, Fakultas Kesehatan Masyarakat, \\ Universitas Indonesia, \\ nimasmayangsari@gmail.com ${ }^{1}$, zulkiflidj59@gmail.com²
}

\begin{abstract}
In the theory of human factors, there are 3 (three) components, namely organizations, individuals and jobs that have an influence on worker behaviour that can affect to safety performance. Organizational aspects have the highest influence compared with individuals doing safe behaviour establishing/designing a safe work environment in a work organization. This paper aims to determine what elements in organizational factors that can affect organizational safety performance. This paper uses the traditional literature review method using the Google Scholar, Science Direct, Taylor \& Francis, Springerlink, and Research Gate search engines. The search uses the keywords safety performance, human factor, organizational factor, worker participation, safety commitment. Based on 12 literatures it was found that in organizational factors there are elements that can affect safety performance such as: management commitment, safety leadership, worker participation, safety policy and promotion, communication, safety training, safety supervision and supervisor support, interpersonal relationships, reward system (including incentives and penalties), blame culture, and continuous improvement
\end{abstract}

Keywords: $\quad$ Human Factor, Organizational Factor, Safety Commitment, Safety Performance, Worker Participation.

ABSTRAK
Di dalam teori faktor manusia terdapat komponen yaitu organisasi, individu dan pekerjaan yang memiliki pengaruh pada tingkah laku pekerja sehingga dapat berdampak pada kinerja keselamatan. Aspek organisasi memiliki pengaruh yang paling tinggi dalam individu/pekerja menjalankan tingkah laku aman dan membentuk/mendesain lingkungan kerja yang aman pada sebuah organisasi kerja . Tulisan ini bertujuan untuk mengetahui elemen-elemen apa saja pada faktor organisasi yang dapat mempengaruhi kinerja keselamatan organisasi. Tulisan ini menggunakan metode traditional literature review dengan menggunakan mesin pencari Google Scholar, Science Direct, Taylor \& Francis, Springerlink, dan Research Gate. Penelusuran menggunakan kata kunci safety performance, human factor, organizational factor, worker participation, safety commitment. Berdasarkan 12 literatur yang didapatkan bahwa dalam faktor organisasi terdapat elemen-elemen yang bisa mempengaruhi kinerja keselamatan seperti: komitmen manajemen, kepemimpinan keselamatan, partisipasi pekerja, kebijakan dan promosi keselamatan, komunikasi, pelatihan keselamatan, pengawasan keselamatan dan dukungan supervisor, hubungan interpersonal, sistem penghargaan (termasuk insentif dan pinalti),budaya menyalahkan, dan perbaikan berkelanjutan.

Kata kunci: Faktor Keselamatan, Faktor Manusia, Faktor Organisasi, Partisipasi Pekerja, Komitmen Keselamatan

\section{PENDAHULUAN}

Pada tahun 1979-1994 terdapat 9 (sembilan) insiden besar dengan kontribusi manusia sebagai penyebab insiden tersebut (HSEUK, 1999). 6 (enam) insiden besar tersebut merupakan insiden keselamatan proses yang berkaitan dengan faktor manusia. Insiden besar tersebut seperti di Milvord UK tahun 1994 mengakibatkan 26 orang cedera, insiden di Pasadena, TX 1989 yang mengakibatkan 23 kematian dan 132 orang cedera, insiden di Bhopal tahun 1984 dengan 8.000 kematian dan 300.000 orang cedera (CCPS, 2007). Pada teori faktor manusia terdapat (tiga) komponen yang 
akan mempengaruhi tingkah laku pekerja yaitu organisasi, induvidu dan pekerjaan. (HSE UK,1999). Tingkah laku pekerja tersebut yang akan mempengaruhi kinerja keselamatan organisasi (Hsu dkk 2012). Dengan melibatkan melibatkan faktor manusia dalam proses kerja memiliki keuntungan yaitu dapat memperkecil kecelakaan, memperkecil hampir celaka dan mengurangi potensi adanya kesalahan pada manusia dan dampaknya (OGP, 2005). Pada teori faktor manusia, organisasi memiliki pengaruh yang paling tinggi dalam individu/pekerja menjalankan tingkah laku aman dan membentuk/mendesain lingkungan kerja yang aman (HSE UK, 1999). Organisasi ini juga memiliki tingkat kepentingan yang paling tinggi dalam memberikan pengaruh pada kinerja keselamatan dibandingan dengan individu dan lingkungan kerja (Eskandari dkk, 2020).

Para pemimpin organisasi sebaiknya dapat mengembangkan strategi untuk meningkatkan iklim keselamatan dalam organisasi sehingga memberikan efek positif pada kinerja keselamatan (Wu dkk, 2008). Strategi keselamatan dengan menerima umpan balik dari karyawan merupakan faktor yang penting dalam kesadaran mengenai isu keselamatan untuk mengukur peningkatan kinerja keselamatan. (Eskandari dkk, 2020). Banyak aspek dari manajemen organisasi yang dapat mempengaruhi kinerja kesehatan dan keselamatan (Smith, 2012). Jika manajemen memiliki sikap yang mengutamakan pertimbangan keselamatan maka karyawan akan mengerahkan energinya kedalam upaya peningkatan kinerja keselamatan. Faktor yang konsisten dalam penyebab cedera adalah tekanan manajemen untuk produksi yang lebih tinggi, atau output yang lebih cepat, atau respons yang cepat terhadap masalah produksi (Smith, 2012).

Organisasi ini memiliki pengaruh pada perilaku/tingkah laku individu dan kelompok. Organisasi perlu membangun budaya keselamatan yang positif untuk mempromosikan partisipasi dan komitmen pekerja dalam upaya peningkatan kinerja dan menekankan bahwa penyimpangan dari standar keselamatan tidak dapat diterima. Contoh faktor organisasi yang dapat menjadi penyebab insiden seperti perencanaan kerja yang buruk, menyebabkan tekanan kerja yang tinggi, kurangnya sistem keamanan dan tanggapan yang tidak memadai untuk insiden sebelumnya, manajemen berdasarkan komunikasi satu arah, koordinasi dan tanggung jawab yang kurang, manajemen kesehatan dan keselamatan yang buruk, budaya kesehatan dan keselamatan yang buruk (HSE UK, 1999). Faktor organisasi memainkan peran penting dalam hampir semua kecelakaan, $40 \%$ elemen yang menjadi penyebab kecelakaan adalah elemen dalam organisasi (Gonçalves,2012). Dengan demikian, penting dalam mengidentifikasi eleme-elemen dalam faktor organiassi sebagai faktor penentu keberhasilan untuk memahami, mencegah, dan mengendalikan kecelakaan ini. Manajemen perlu memastikan bahwa pelaksanaan faktor organisasi telah dijalankan dengan baik.

Tujuan dari penelitian ini untuk mengetahui elemen-elemen apa saja dalam faktor organisasi yang dapat mempengaruhi tingkah laku pekerja untuk bekerja secara aman sehingga dapat berdampak baik pada kinerja keselamatan.

\section{METODE}

Tulisan ini menggunakan metode traditional literature review dengan menggunakan mesin pencari Google Scholar, Science Direct, Taylor \& Francis, Springerlink, dan Research Gate. Penelusuran menggunakan kata kunci safety performance, human factor, organizational factor, worker participation, safety commitment. Literatur yang digunakan dalam makalah ini menggunakan bahasa inggris dengan total jumlah 12 literatur. Tahun terbit dipilih pada tahun 2010-2021. 
HASIL

Hasil pencarian dengan traditional literature review memberikan hasil yang tercantum pada Tabel 1. Hasil ini akan memberikan elemen-elemen dalam organisasi yang akan dibahas dalam tulisan ini.

Tabel 1 Hasil Traditional Literature Review

\begin{tabular}{lll}
\hline Penulis Jurnal & Tahun & Judul Jurnal \\
\hline M. N. Vinodkumar, M. Bhasi & 2010 & $\begin{array}{l}\text { Safety management practices and safety } \\
\text { behaviour: Assessing the mediating } \\
\text { role of safety knowledge and motivation }\end{array}$ \\
\hline $\begin{array}{l}\text { Abid Hasan and Kumar Neeraj } 2013 \\
\text { Jha }\end{array}$ & $\begin{array}{l}\text { Safety incentive and penalty provisions in } \\
\text { Indian construction projects and their } \\
\text { impact } \\
\text { on safety performance }\end{array}$ \\
\hline
\end{tabular}

Julie M. Sampson, Sarah $2014 \quad$ Role of safety stressors and social support

Xianguo Wu, Qian Liu, Limao 2015 Prospective safety performance evaluation DeArmond, Peter Y. Chen Zhang, Miroslaw J. Skibniewski, Yanhong Wang

\begin{tabular}{|c|c|}
\hline $\begin{array}{l}\text { Abid Hasan and Kumar Neeraj } \\
\text { Jha }\end{array}$ & 2013 \\
\hline $\begin{array}{l}\text { Julie M. Sampson, Sarah } \\
\text { DeArmond, Peter Y. Chen }\end{array}$ & 2014 \\
\hline Xianguo Wu, Qian Liu, Limao & 2015 \\
\hline $\begin{array}{l}\text { Zhang, Miroslaw J. } \\
\text { Skibniewski, Yanhong Wang }\end{array}$ & \\
\hline $\begin{array}{l}\text { Yuting Chen, Brenda } \\
\text { McCabe, Douglas Hyatt }\end{array}$ & 2017 \\
\hline $\begin{array}{l}\text { Beatriz Fernández-Muñiz, José } \\
\text { Manuel Montes-Peón, Camilo } \\
\text { José Vázquez-Ordás }\end{array}$ & 2017 \\
\hline \begin{tabular}{lr} 
Davood & \multicolumn{2}{c}{ Eskandari, } \\
Mohammad Javad Jafari, \\
Yadollah Mehrabi, Mostafa \\
Pouyakin, \\
Charkhand, Mustafa Mirghotbi
\end{tabular} & 2017 \\
\hline
\end{tabular}

McCabe, Douglas Hyatt

\begin{abstract}
Mohammad Javad Jafari, 201
Davood Eskandari, Firouz

Valipouc, Yadollah Mehrabi,

Hossein Charkhand and

Mostafa Mirghotbi
\end{abstract}

Impact of individual resilience and safety climate on safety performance and psychological stress of construction workers: A case study of the Ontario construction industry

The role of safety leadership and working conditions in safety performance in process industries

A Qualitative Study on Organizational Factors Affecting Occupational Accidents
Elemen dalam Organisasi

1. Komitmen Manajemen

2. Partisipasi pekerja

3. Kebijakan dan promosi keselamatan

4. Pelatihan keselamatan

1. Insentif keselamatan

2. Pinalti keselamatan

1. Dukungan Supervisor

2. Partisipasi pekerja

3. Komunikasi

4. Pelatihan keselamatan

5. Pengawasan keselamatan

6. Sistem penghargaan

1. Manajemen komitmen

2. Pengawasan keselamatan

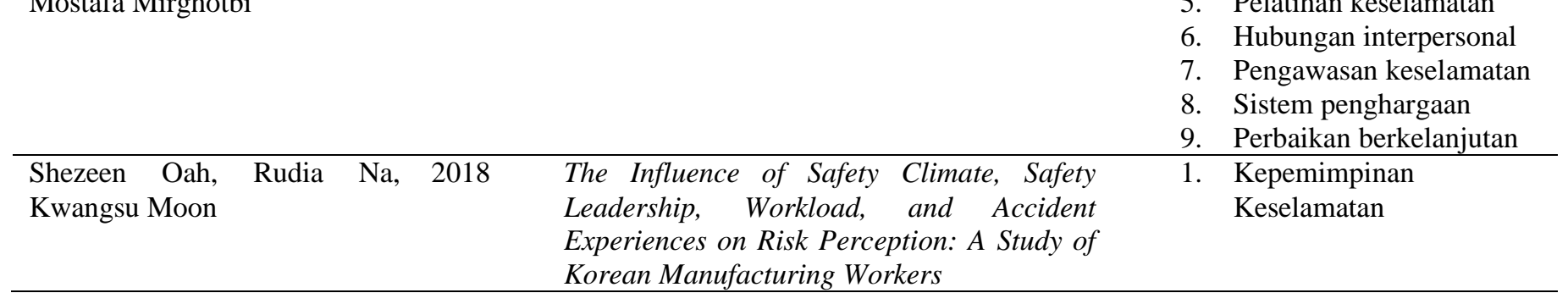




\begin{tabular}{|c|c|c|c|}
\hline $\begin{array}{l}\text { Ying Lu, Lucy } \text { Taksa, } \\
\text { Hongguo Jia }\end{array}$ & 2020 & $\begin{array}{l}\text { Influence of management practices on safety } \\
\text { performance: The case of mining sector in } \\
\text { China }\end{array}$ & $\begin{array}{ll}\text { 1. } & \text { Komitmen Manajemen } \\
\text { 2. } & \text { Kebijakan dan promosi } \\
\text { keselamatan }\end{array}$ \\
\hline $\begin{array}{l}\text { Davood Eskandari, Mousa } \\
\text { Jabbari Gharabagh, Abdullah } \\
\text { Barkhordari, Noradin Gharari, } \\
\text { Davoud Panahi, Abdollah } \\
\text { Gholami,Gholamheidar } \\
\text { Teimori-Boghsani }\end{array}$ & 2020 & $\begin{array}{l}\text { Development of a scale for assessing the } \\
\text { organization's safety performance } \\
\text { based fuzzy ANP }\end{array}$ & $\begin{array}{ll}\text { 1. } & \text { Komitmen manajemen } \\
\text { 2. } & \text { Partisipasi pekerja } \\
\text { 3. } & \text { Kebijakan dan promosi } \\
\text { keselamatan } \\
\text { 4. Komunikasi } \\
\text { 5. } \\
\text { 6. Pelatihan keselamatan } \\
\text { 7. Hubungan interpersonal } \\
\text { 8. Pengawasan keselamatan } \\
\text { 9. } \text { Sistem penghargaan } \\
\text { 10. } \\
\text { Perbaikan berkelanjutan }\end{array}$ \\
\hline $\begin{array}{l}\text { Ruipeng Tong, Xiaoyi Yang, } \\
\text { Trent Parker, Boling Zhang, } \\
\text { Qingsheng Wang }\end{array}$ & 2020 & $\begin{array}{l}\text { Exploration of relationships between safety } \\
\text { performance and unsafe behavior in the } \\
\text { Chinese oil industry }\end{array}$ & 1. Partisipasi keselamatan \\
\hline
\end{tabular}

\section{PEMBAHASAN}

Pada teori Faktor Manusia terdapat 3 aspek yang mempengaruhi tingkah laku pekerja pada keselamatan yaitu organisasi, individu, dan pekerjaan (HSE UK, 1999). Model dari sistem kerja terdiri dari 5 elemen yaitu individu (person), tugas (tasks), lingkungan (environment), organisasi (organization) dan peralatan dan teknologi (technologies and tools) (Carayon, 2012). Aspek organisasi merupakan aspek yang paling penting sehingga perlu diketahui elemen-elemen apa saja pada organisasi yang mempengaruhi perilaku pekerja sehingga menghasilkan kinerja keselamatan yang baik. Dari hasil studi literatur di tabel 1 terdapat 11 (dua belas) elemen dalam faktor organisasi yang mempengaruhi kinerja keselamatan. Elemen tersebut adalah komitmen manajemen, kepemimpinan keselamatan, partisipasi pekerja, kebijakan dan promosi keselamatan, komunikasi, pelatihan keselamatan, pengawasan keselamatan dan dukungan supervisor, hubungan interpersonal, sistem

Komitmen manajemen mempengaruhi secara langsung pada kepatuhan keselamatan pekerja (Vinodkumar \& Bhasi, 2010 \& Lu, dkk, 2020) dan partisipasi keselamatan (Lu dkk, 2020). Tanpa komitmen, kinerja dari manajemen keselamatan hampir pasti akan gagal (Wu penghargaan (termasuk insentif dan pinalti),budaya menyalahkan, dan perbaikan berkelanjutan. Seluruh elemen tersebut akan dibahas pada bab ini.

\section{Elemen Komitmen Manajemen}

Komitmen manajemen merupakan elemen penting dalam organisasi yang mempengaruhi kinerja keselamatan (Vinodkumar \& Bhasi, 2010; FernándezMuñiz dkk, 2017; Lu dkk, 2020; Eskandari dkk, 2020). Komitmen ini akan memberikan motivasi kepada karyawan bahwa organisasi akan menyediakan sumber daya yang dibutuhkan untuk mendukung kinerja keselamatan (Jafari dkk, 2017) sehingga dapat memberikan efek langsung terhadap kepatuhan dan patisipasi pekerja pada keselamatan (Lu dkk, 2020). Sumber daya yang dibutuhkan seperti keuangan, personel, waktu serta dukungan lainnya seperti pelatihan, pembuatan program keselamatan dan kesehatan kerja dan pertimbahan keselamatan kerja dalam pengambilan keputusan (Jafari dkk, 2017).

$\mathrm{dkk}, 2015)$. Komitmen manajemen dapat dilakukan dengan berbagai cara seperti, tim manajemen mengikuti Ini dapat dicapai dengan banyak cara, sebagai contoh: manajemen dapat mengikuti dan terlibat dalam agenda komite keselamatan dan pelatihan keselamatan; alokasi sumber daya 
keselamatan yang baik; manajemen sering menyatakan kebijakan keselamatan; manajemen melibatkan personel dalam keputusan yang mempengaruhi keselamatan pekerjaan mereka, dan lainlain (Wu dkk, 2008).

\section{Elemen Kepemimpinan Keselamatan}

Kepemimpinan keselamatan juga memiliki efek pada kinerja keselamatan walaupun secara tidak langsung melalui kondisi kerja (Fernández-Muñiz dkk, 2017). Pekerja yang bekerja pada perusahaan dengan kepemimpinan keselamatan yang baik dan memiliki iklim yang positif merasakan risiko kecelakaan yang lebih rendah daripada pekerja yang memiliki kepemimpinan dan iklim keselamatan yang lebih rendah. (Oah, Na, \& Moon, 2018).. Iklim keselamatan secara parsial memediasi hubungan antara kepemimpinan keselamatan dan kinerja keselamatan. Elemen kepemimpinan keselamatan, memiliki pengaruh utama pada komitmen dan tindakan keselamatan manajemen puncak dalam mendukung iklim keselamatan, menyediakan peralatan dan tindakan keselamatan, pelaksanaan investigasi kecelakaan dalam kinerja keselamatan. Hasil analisis statistik menunjukkan bahwa pemimpin organisasi sebaiknya mengembangkan strategi yang dapat meningkatkan iklim keselamatan sehingga berdampak positif pada kinerja keselamatan (Wu dkk, 2008)

\section{Elemen Partisipasi Pekerja}

Partisipasi pekerja merupakan salah satu elemen dalam faktor organisasi yang mempengaruhi kinerja keselamatan (Vinodkumar \& Bhasi, 2010; Wu dkk, 2015; Jafari dkk, 2017; Eskandari dkk, 2017; Fernández-Muñiz dkk, 2017; Chen dkk, 2017, Eskandari dkk, 2020). Partisipasi pekerja ini mengajak pekerja berperan dan terlibat dalam pencapaian kinerja keselamatan (Jafari dkk, 2017). Partisipasi pekerja dalam bentuk ide dan proposal program kerja ini membutuhkan dukungan manajemen sehingga pekerja dapat merasa benar-benar telah ikut serta dalam merancanakan dan melaksanakan perbaikan di area kerja (Jafari dkk, 2017). Hasil penelitian pada industri proses, pekerja minyak di Cina menunjukan bahwa partisipasi dan kepatuhan pada keselamatan berkontribusi pada penurunan perilaku tidak aman (Tong dkk, 2020). Tetapi hal tersebut dapat dirusak oleh kelelahan kerja, kondisi psikologis pekerjaan negatif. Sehingga faktor individu seperti kelelahan dan faktor psikologis juga harus dipertimbangkan oleh manajemen perusahaan (Tong dkk, 2020). Jika organisasi ingin meningkatkan partisipasi karyawan dalam kegiatan keselamatan kerja seperti : pertemuan, audit atau pelaporan aktif tindakan tidak aman dan kondisi tidak aman di tempat kerja, organiassi harus memberikan pelatihan kepada sekelompok karyawan yang dapat bertindak sebagai agen perubahan untuk mempromosikan partisipasi karyawan daripada komunikasi resmi melalui supervisor (Puah dkk, 2018)

\section{Elemen Kebijakan dan Promosi Keselamatan}

Kebijakan dan promosi keselamatan salah satu dari faktor organisasi yang mempengaruhi kinerja keselamatan (Vinodkumar \& Bhasi, 2010; Eskandari dkk, 2020; Lu dkk, 2020). Promosi keselamatan dapat mempengaruhi kinerja keselamatan secara langsung. Peran penting praktik promosi keselamatan di tempat kerja akan berdampak pada pengetahuan dan motivasi pekerja (Lu dkk, 2020). Kebijakan harus dibuat agar pekerja memandang kebijakan keselamatan sebagai kebijakan yang dibuat oleh dan untuk kepentingan terbaik organisasi. Organisasi harus dapat menginternalisasi kebijakan dengan melihat hubungan antara kepatuhan dan operasi yang aman (Hofmann dkk, 1995)

\section{Elemen Komunikasi Keselamatan}

Komunikasi keselamatan dilakukan tidak hanya dalam bentuk komunikasi dari 
atasan ke bawahan tetapi juga harus dari bawahan ke atasan. Pekerja harus dapat berbagi pandangan mereka dengan manajemen. Manajemen harus menunjukkan umpan balik terhadap saran dan harapan dari pekerja. Jika tidak ada umpan balik, maka pekerja akan merasa apa yang sudah dikomunikasikan tidak berguna sehingga tidak ada keinginan lagi untuk melaporkan masalah, padahal pekerja mungkin menanggapi dan memberikan solusi dari kritik dan saran manajemen sesuai kebijakan perusahaan (Eskandari dkk, 2017).Organisasi harus berusaha mengembangkan metode komunikasi formal dan informal untuk menyampaikan informasi di dalam dan di antara tingkat organisasi. Organisasi harus memberikan dukungan teknis dan manajemen agar pekerja dapat berkomunikasi secara efekti terkait dengan pekerjaan antar area kerja (Hofmann dkk, 1995). Bentuk komunikasi umum/informal antara supervisor dan pekerja konstruksi mungkin memiliki efek menguntungkan pada kinerja keselamatan. Sehingga dalam membentuk komunikasi dengan pekerja tidak hanya fokus pada komunikasi yang berhubungan dengan pekerjaan (Sampson, DeArmond, \& Chen, 2014).

\section{Elemen Pelatihan Keselamatan}

Pelatihan keselamatan memiliki peran penting dalam kinerja keselamatan sehingga harus menjadi prioritas manajemen (Vinodkumar \& Bhasi, 2010). Kurangnya pelatihan pekerja atau pelatihan yang tidak memadai adalah salah satu penyebab tingginya angka kecelakaan. Pelatihan keselamatan dapat mempengaruhi partisipasi pekerja dengan adanya pengetahuan dan motivasi (Lu dkk, 2020) dengan demikian dapat meningkatkan iklim keselamatan (Singh \& Misra, 2021). Pelatihan keselamatan dapat lebih dapat memotivasi pekerja daripada memberikan penghargaan dan insentif bagi pekerja yang bertingkah laku aman (Vinodkumar \& Bhasi, 2010). Pelatihan keselamatan dan bahaya di tempat kerja berdampak pada pengembangan pengetahuan keselamatan dan kinerja keselamatan. Adanya keterlibatan pekerja dalam pelatihan jauh lebih efektif daripada pelatihan yang kurang menarik ketika tingkat keparahan paparan bahaya tinggi. Sedangkan pelatihan yang sangat dan kurang melibatkan pekerja memiliki tingkat efektivitas yang sebanding ketika tingkat keparahan paparan bahaya rendah (Burke,2011)

\section{Elemen Pengawasan Keselamatan dan Dukungan Supervisor}

Pengawasan keselamatan lingkungan kerja merupakan salah satu faktor kunci dalam pencegahan kecelakaan kerja (Eskandari dkk, 2017) Untuk pengawasan keselamatan kerja yang efektif supervisor perlu dilatih. Kontraktor harus ada rencana pengawasan rutin karena kurangnya pengawasan dapat mengabaikan persyaratan keselamatan dan kesehatan kerja, terutama jika ada kebutuhan untuk mempercepat pekeerjaan. Pengawasan tidak memberi tahu seseorang apa yang harus dilakukan dan bagaimana melakukannya. Pengawasan adalah untuk memastikan karyawan mengikuti instruksi keselamatan dan bekerja dengan aman (Eskandari dkk, 2017). Pekerja menganggap supervisor sebagai agen organisasi, mereka akan mematuhi kebijakan, prosedur, dan praktik perusahaan di bawah pengawasan atasan mereka (Puah, 2016). Pelanggaran rutin terhadap prosedur keselamatan dan kesehatan kerja perusahaan dapat mengindikasi bahwa supervisor telah gagal memainkan peran dalam memperkuat kepatuhan pekerja sehingga manajemen harus mengambil tindakan yang diperlukan untuk meningkatkan keterampilan pengawasan dalam intervensi keselamatan. Mungkin manajemen dapat menetapkan sistem manajemen konsekuensi yang mencakup supervisor dan pekerja jika gagal mematuhi prosedur dan praktik keselamatan kerja, Komunikasi umum antara supervisor dan pekerja konstruksi 
mungkin memiliki efek menguntungkan pada kinerja keselamatan. (Sampson dkk, 2014). Dukungan dari organisasi, supervisor dan rekan kerja berhubungan signifikan dengan kepatuhan keselamatan kerja karyawan. Dukungan supervisor memiliki pengaruh paling kuat dalam memastikan perilaku kepatuhan keselamatan pekerja (Puah dkk, 2016)

\section{Elemen Hubungan Interpersonal}

Elemen hubungan interpersonal dapat mengacu pada hubungan antara pekerja dan supervisor. Supervisor dan pekerja dapat mendiskusikan masalah apa pun secara terbuka di tempat kerja. Supervisor harus berperilaku sehingga karyawan terlibat dalam aktivitas keselamatan, dan merasa pendapat mereka penting bagi supervisor. Supervisor dapat meningkatkan iklim organisasi dengan mendekatkan karyawan, sehingga mengurangi gesekan dan kesalahpahaman. Supervisor adalah jembatan antara manajer dan karyawan, dan perilaku mereka harus mendapat kepercayaan pekerja dan tidak takut untuk mengungkapkan masalah (Eskandari, 2017). Pada penelitian di lokasi konstruksi didapatkan adanya korelasi positif antara konflik interpersonal di tempat kerja dan terjadinya insiden keselamatan. Saat ini ditemukan lebih sedikit konflik interpersonal dibandingkan dengan sepuluh tahun lalu. Kurangnya tekanan kerja dapat menjelaskan berkurangnya konflik. Perusahaan konstruksi dapat berinvestasi dalam membangun program pelatihan yang berfokus pada peningkatan kemampuan mengatasi orang (Chen dkk, 2019)

\section{Elemen Sistem Penghargaan}

Elemen sistem penghargaan dapat menciptakan motivasi bagi karyawan untuk berperilaku aman. Ada dua jenis dasar penghargaan yaitu penghargaan secara finansial dan non-finansial. Keduanya dapat diterapkan secara positif untuk memperkuat perilaku pekerja. Penghargaan finansial dapat berupa insentif, gaji, promosi, bonus, keamanan kerja, dll.
Penghargaan non-finansial adalah penghargaan psikologis seperti sikap positif dan kepedulian dari pemberi kerja, memenuhi tantangan baru, dan rotasi pekerjaan setelah mencapai tujuan (Eskandari dkk, 2017). Pada proyek konstruksi di India, penggunaan ketentuan insentif/penalti keselamatan menghasilkan jumlah kecelakaan yang lebih sedikit dan kinerja keselamatan yang lebih baik jika dibandingkan dengan proyek tanpa ketentuan insentif/pinalti yang dirumuskan dan diterapkan dengan cara yang tepat. Cara pemberian insentif dapat berupa penghargaan dan pengakuan dari klien kepada kontraktor untuk memberikan motivasi. Penghargaan ini harus secara holistik didasarkan pada perilaku yang aman dan semangat tim dan bukan hanya pada non-insiden cedera/kecelakaan saja (Hasan \& Jha, 2013). Insentif/pinalti juga harus bersamaan dengan mempertimbangkan hal lain seperti pemberian pelatihan kepada pekerja, memberikan pertimbangan khusus untuk tugas-tugas khusus dan situasi berisiko, mengakui peran komite keselamatan dan subkontraktor, dan memelihara inventaris peralatan keselamatan yang baik (Hasan \& Jha, 2013).

\section{Elemen Budaya Menyalahkan}

Elemen budaya menyalahkan penting dalam penentu kinerja keselamatan. Organisasi harus menciptakan budaya dan lingkungan yang sesuai bagi karyawan untuk melaporkan kesalahan tanpa takut konsekuensinya. Dalam organisasi di mana orang takut menceritakan sebenarnya maka pekerja mungkin tidak akan melaporkan kejadian nearmiss dan kecelakaan. Menyalahkan pekerja adalah pendekatan tradisional, hal ini menyebabkan pekerja kehilangan motivasinya, menjadi kecewa, dan mungkin melakukan tindakan balas dendam (Eskandari, 2017)

\section{Elemen Perbaikan Berkelanjutan}

Elemen lain dari faktor organisasi lain yang mempengaruhi kecelakaan kerja 
adalah perbaikan berkelanjutan. Perbaikan berkelanjutan harus mencakup semua individu, termasuk manajer, karyawan, dan pekerja. Organisasi harus memiliki rencana jangka panjang untuk meningkatkan situasi keselamatan dan tujuan tercapai ketika tindakan korektif direncanakan dan dilaksanakan. Sistem manajemen kesehatan dan keselamatan kerja diperlukan untuk

\section{KESIMPULAN}

\begin{abstract}
Organisasi memiliki beberapa elemen yang dapat mempengaruhi kinerja keselamatan yaitu terkait dengan komitmen manajemen, kepemimpinan keselamatan, partisipasi pekerja, kebijakan dan promosi keselamatan, komunikasi, pelatihan keselamatan, pengawasan keselamatan dan dukungan supervisor, hubungan interpersonal, sistem penghargaan (termasuk insentif dan pinalti), budaya menyalahkan, dan perbaikan berkelanjutan. Untuk meningkatkan kinerja keselamatan perusahaan disarankan untuk tidak hanya fokus pada organisasi, tetapi juga melakukan mempertimbangkan elemen lain dari faktor manusia seperti individu, pekerjaan, lingkungan dan teknologi.
\end{abstract}

\section{UCAPAN TERIMAKASIH}

Penulis mengucapkan terima kasih sebesar-besarnya Pembimbing Akademik Universitas Indonesia, teman-teman Magister K3 FKM UI 2019 dan beberapa pihak lainya yang saya tidak bisa sebut satu persatu.

\section{DAFTAR PUSTAKA}

Chen, Y., McCabe, B., \& Hyatt, D. (2017). Impact of individual resilience and safety climate on safety performance 2 and psychological stress of construction workers: A case study of the 3 Ontario construction industry. Journal of Safety Research, 10. menghilangkan atau mengurangi risiko terhadap personel dan pihak berkepentingan lainnya yang terpapar bahaya kesehatan dan keselamatan yang timbul dari operasi. Dengan sistem manajemen keselamatan mencapai perbaikan berkelanjutan (Eskandari dkk, 2017).

Eskandari, D., Gharabagh, M. J., Barkhordari, A., Gharari, N., Panahi, D., Gholami, A., \& TeimoriBoghsani, G. (2020). Development of a scale for assessing the organization's safety performance based fuzzy ANP. Journal of Lost Prevention in the Process Industries, 10.

Eskandari, D., Jafari, M. J., Mehrabi, Y., Pouyakian, M., Charkhand, H., \& Mirghotbi, M. (2017). A Qualitative Study on Organizational Factors Affecting Occupational Accidents. Iranian Journal of Public Health, 46(3), 9.

Fernández-Muñiz, B., Montes-Peón, J. M., \& Vázquez-Ordás, C. J. (2017). The role of safety leadership and working conditions in safety performance in process industries. Journal of Lost Prevention in the Process Industries, $50,13$.

Hasan, A. \& Jha, K. N. (2012). Safety incentive and penalty provisions in Indian construction projects and their impact on safety performance. International Journal of Injury Control and Safety Promotion, 20:1, 3-12.

Hsu, I.-Y., Su, T.-S. Kao, C.-S., Shu, Y.-L., Lin, P.-R., \& Tseng, J.-M. (2012). Analysis of business safety performance by structural equation models. Safety Science, 50, 11.

Jafari, M. J., Eskandari, D., Valipour, F., Mehrabi, Y., Charkhand, H., \& Mirghotbi, M. (2017). Development and validation of a new safety 
climate scale for petrochemical industries. 9.

Li, W., Liang, W., Zhang, L., \& Tang, Q. (2015). Performance assessment system of health, safety and environment based on experts' weights and fuzzy comprehensive evaluation. Journal of Lost Prevention in the Process Industries, $35,9$.

Lu, Y., Taksa, L., \& Jia, H. (2020). Influence of management practices on safety performance: The case of mining sector in China. Safety Science, 132, 11.

Martínez-Córcoles, M., Gracia, F. J., Tomás, I., Peiró, J. M., \& Schöbel, M. (2013). Empowering team leadership and safety performance in nuclear power plants: A multilevel approach. Safety Science, 51, 9.

Sampson, J. M., DeArmond, S., Chen, P. Y. (2014). Role of safety stressors and social support on safety performance. Safety Science, 64, 137-145.

Singh, A., \& Misra, S. C. (2021). Safety performance \& evaluation framework in Indian construction industry. Safety Science, 134, 16.

Tang, K. H. D., Dawal, S. Z. M., \& Olugu, E. U. (2018). Integrating fuzzy expert system and scoring system for safety performance evaluation of offshore oil and gas platforms in Malaysia. Journal of Lost Prevention in the Process Industries, 56, 14.

Tong, R., Yang, X., Parker, T., Zhang, B., \& Wang, Q. (2020). Exploration of relationships between safety performance and unsafe behavior in the Chinese oil industry. Journal of Lost Prevention in the Process Industries, 66, 9.

Vinodkumar, M. N., \& Bhasi, M. (2010). Safety management practices and safety behaviour: Assessing the mediating role of safety knowledge and motivation. Accident Analysis and Prevention, 42, 12.
Wu, T.-C., Chen, C.-H., \& Li, C.-C. (2008) A correlation among safety leadership, safety climate and safety performance. Journal of Loss Prevention, 21, 307-318.

Wu, X., Liu, Q., Zhang, L., Skibniewski, M. J., \& Wang, Y. (2015). Prospective safety performance evaluation on construction sites. Accident Analysis and Prevention, $78,15$. 